\title{
A TÖMEGBETONOK HŐÁTADÁSI TÉNYEZŐJÉNEK BECSLÉSI MÓDSZERE
}

\section{ESTIMATION METHOD FOR HEAT TRANSFER COEFFICIENT OF MASS CONCRETE}

\author{
Domonyi Erzsébet ${ }^{1}$, M. Csizmadia Béla ${ }^{2}$, Zachár András ${ }^{2}$ \\ ${ }^{I}$ Szent István Egyetem, Ybl Miklós Épitéstudományi Kar, Épitőmérnöki Intézet, Épi- \\ töanyagok Szakcsoport Cím: 1146, Magyarország, Budapest, Thököly út 74. Tele- \\ fon:+36-1-2521270/136, Domonyi.Erzsebet@ybl.szie.hu \\ ${ }^{2}$ Szent István Egyetem, Gépészmérnöki Kar, Mechanika Tanszék, Cím: 2100, Ma- \\ gyarország, Gödöllö, Páter Károly u. 1.
}

\begin{abstract}
In mass concrete the heat released during the cement hydration causes temperature difference between the core and the surface due to the different heat transmissions. This results considerable danger of cracking in the structure. The thermal connection between the structure and the environment is described by the heat transfer coefficient. This value is only estimated in the related literature, other method is not provided. Present research aims to use complex numerical model for estimating this value, by modeling the thermal behavior of a concrete cube surrounded by considerable amount of air thus providing more reliable method for concrete technologist to avoid destruction of the structure.
\end{abstract}

Keywords: mass concrete, heat of hydration, avoiding cracking finite element method.

\section{Összefoglalás}

A tömegbetonokban a cement hidratációja során felszabaduló hőmennyiség, a mag és felszín között létrejövő különböző hőelvonás miatt, hőmérséklet-különbséget eredményez. Ez jelentős repedésveszélynek teszi ki a szerkezetet. A szerkezet és a környezet közötti termikus kapcsolatot a höátadási tényező fejezi ki. Ennek értékét a szakirodalom becsli, nem ad módszert a meghatározására. Kutatásunk célja, hogy ennek a tényezőnek az átlagértékét egy összetett numerikus modellel becsüljük, amelynél a tömegbeton kockának a termikus viselkedését az azt körülvevő, jelentős méretű levegővel együtt modellezzük. Így a betontechnológusok számára megbízhatóbb, a szerkezet tönkremenetelét elkerülendő módszert adhatunk.

Kulcsszavak: tömegbeton, hidratációs hömennyiség, repedésveszély elkerülése, végeselemmódszer.

\section{Bevezetés}

Beton kötési szakaszában, a cementnek víz hatására végbemenő vegyi reakciója eredményeként, hő keletkezik. Ez a cementhidratációs hőmennyiség jellemzően a cement minőségének a függvénye. A keletkező hő elvezetését közönséges betonok ese- tében többnyire a betonfelület hütésével oldják meg.

A különleges technológiával készített, $u$. n. tömegbetonok (hídpillérek, gátak, siló- és erőmüalapok, stb.) geometriájából adódóan a szerkezet belsejében a felülettől távol eső részek lassabban hülnek, így a belső részek és a felület között jelentős $\Delta \mathrm{T}$ hőmérsékletkülönbség jöhet létre. Az ebből adódó kü- 
lönböző térfogati hö-tágulások eredményeként, a mag rész nagyobb méretnövekedése a felületi részeken húzó feszültségeket eredményez, amelyek felületi repedésekhez vezethetnek. A repedésveszély elkerülésére a megengedhető legnagyobb keletkező hökülönbséget elóírják, amelyet a megfelelő betontechnológia megválasztásával kísérelnek meg biztosítani [2],[3].

A betontechnológusok jelenleg leginkább a gyakorlati tapasztalatokra támaszkodnak. A megfelelőnek tartott betonösszetétel kialakítása után szabványos méretü próbatestet készítenek, amelynek nyomószilárdsági, fagyállósági vizsgálatát végzik el. Ez a vizsgálat azonban nem ad eredményt a beton tartósságát illetően, valamint a próbatest méreteiből adódóan nem lehet következtetni az esetlegesen kialakuló hőmérséklet-különbség okozta repedésveszélyre sem.

A kutatók a szakirodalomban - az általánosíthatóság érdekében - egyrészt laboratóriumi kísérletek eredményét ismertetik, amelyeket irányított körülmények között végeztek. Másrészt többféle numerikus eljárást mutatnak be és vetnek össze a laboratóriumi mérésekkel. Ezekben a számításokban a hidratációs hőmennyiség hatására létrejövő hőmérséklet-eloszlást határozták meg, a mért hidratációs hőmennyiség-idő függvényt figyelembe véve. A feladatmegoldások során elsősorban a hővezetés differenciál-egyenletét alkalmazzák homogén hidratációs hőmennyiség eloszlás és anyagszerkezet esetén [1],[4],[5]. Ugyanakkor hiába veszik figyelembe hőeloszlásra ható más jellemzőket, mint például szakaszos betonozást és az építési sebességet (G. De Schutter (2004) VEM modellje [2]), ha az eredményeket meghatározó alapvető öt paraméterben bizonytalanságok vannak. Ez az öt paraméter pedig a $\rho$ testsürüség, a q kötés hőmennyisége az idő függvényében, a $c_{p}$ fajhő, a $\lambda$ hővezetési tényező és a $h$ höátadási tényező. A beton fajtájától függően az első két jellemző jól kézben tartható, a kö- vetkezö kettőre vonatkozóan vannak adatok, ha nehezen is, de mérhetőek. A hőátadási tényező azonban szinte minden esetben becsült átlag érték. Az utolsó három paraméterre vonatkozóan az alábbi táblázat ad útmutatást néhány irodalomban felhasznált adatról.

1. táblázat. Hömérsékleti mezők numerikus számításánál használt anyagtulajdonságok

\begin{tabular}{|c|c|c|c|c|}
\hline \multicolumn{2}{|c|}{ Szakirodalom } & {$[2]$} & {$[3]$} & {$[4]$} \\
\hline \multicolumn{2}{|c|}{$\mathrm{c}_{\mathrm{p}}[\mathrm{J} / \mathrm{kg} \mathrm{K}]$} & 880 & 960 & 1228 \\
\hline \multicolumn{2}{|c|}{$[\mathrm{W} / \mathrm{mK}]$} & 2,66 & 1,96 & 3,5 \\
\hline \multirow{2}{*}{$\begin{array}{c}\mathrm{h} \\
{\left[\mathrm{W} / \mathrm{m}^{2} \mathrm{~K}\right]}\end{array}$} & $\begin{array}{c}\text { Szabad } \\
\text { felület }\end{array}$ & 20 & 10 & 30 \\
\cline { 2 - 5 } & $\begin{array}{c}\text { Zsaluzott } \\
\text { felület }\end{array}$ & 6,42 & 3,58 & 5 \\
\hline
\end{tabular}

Az 1. táblázat adataiból látszik, hogy az egyes szerzők a numerikus számításaik során igen nagy különbségekkel vették fel a beton termikus anyagtulajdonságait. Mindezt úgy tették, hogy nem mondták meg, hogyan határozták meg ezeket a bemenő adatokat, és legtöbbször azt sem, hogy milyen anyagösszetétel esetén tartják ezeket meghatározónak. Ezeknek a bemenő adatoknak a hitelessége kérdéses. Ez különösen akkor figyelemre méltó, amikor a számított és mért adatok közötti jó egyezésről is beszélnek. Mindez elsősorban a konvektív hőátadási tényező esetén érdekes, mivel annak közvetlen mérése nem lehetséges.

A továbbiakban arra kívánunk módszert bemutatni, hogyan becsülhető ez a jellemzö.

\subsection{Célkitűzés}

Végső soron egy olyan numerikus számítási módszert szeretnénk kidolgozni, amely a tömegbetonokban keletkező legnagyobb hőmérsékleti különbségek meghatározására szolgál a különböző betontechnológiai paraméterek hatását figyelembe véve. Mindezt úgy, hogy a modell helyességét kísérleti módszerekkel is igazoljuk. Jelen cikkben, első lépésként, bemutatjuk az a 
módszert, amellyel a betonfelület és a különböző közegek közötti hőátadási tényező meghatározható. Ez a jellemző függvénye a betonnal érintkező anyagnak (levegö, szigetelés, zsalu), és az ezt hütő (szél), fütő (napsugárzás) környezetnek. Most a módszert mutatjuk be és néhány numerikus eredményt, valamint a továbblépés lehetőségét. A módszer előnye, hogy szétválasztja a különböző hatásokat, így alkalmazásával a számítógépes idő nagymértékben csökkenhet és az eredmények alkalmazhatósága kiszélesedik.

\section{A hő- és áramlástechnikai prob- léma fizikai és geometriai mo- dellje}

Egy betontömb (1x1x1 m) hőmérsékleti mezejének meghatározására numerikus számításokat végeztünk Ansys CFX modullal. Az 1. ábra a betontest, az azt körülvevő levegő és talaj geometriáját mutatja. A levegö $5 \times 5 \times 3 \mathrm{~m}$, a talaj $0,2 \mathrm{~m}$ vastag.

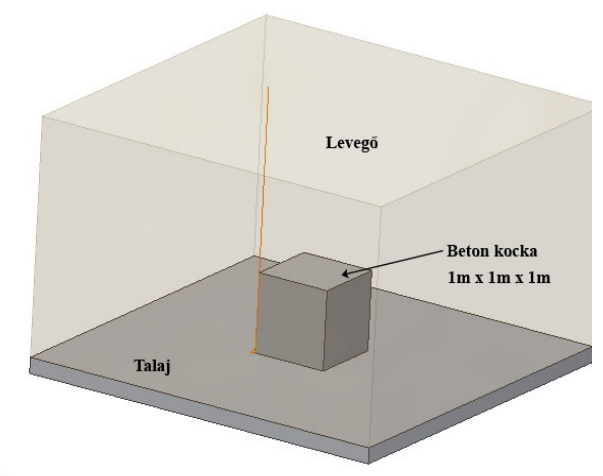

1. ábra. A tanulmányozott hö- és áramlástechnikai probléma geometriai modellje

\section{Matematikai modell}

Az alábbi egyenletek (1)-(3) az előző fejezetben ismertetett hő- és áramlástechnikai probléma matematikai leírását adják. Az egyenletek az anyag, impulzus és az energia megmaradást írják le matematikai alakban.
Folytonossági egyenlet.

$\frac{\partial}{\partial t}(\rho)+\frac{\partial}{\partial x_{i}}\left(\rho U_{i}\right)=0$

$\mathrm{Az}$ összenyomhatatlannak feltételezett folyadék mozgását leíró egyenletek három skaláris komponense tenzor jelölésmódban.

$\frac{\partial}{\partial t}\left(\rho U_{j}\right)+\frac{\partial}{\partial x_{i}}\left(\rho U_{j} U_{i}\right)=-\frac{\partial P}{\partial x_{j}}+\frac{\partial}{\partial x_{i}}\left(\eta\left(\frac{\partial U_{j}}{\partial x_{i}}\right)\right)$

$\mathrm{Az}$ energiatranszportot leíró differenciálegyenlet.

$\frac{\partial}{\partial t}\left(\rho c_{P} T\right)+\frac{\partial}{\partial x_{i}}\left(\rho c_{P} U_{i} T\right)=\frac{\partial}{\partial x_{i}}\left(\lambda\left(\frac{\partial T}{\partial x_{i}}\right)\right)$

A 2. ábra egy numerikus rácsot mutat. $\mathrm{Az}$ ábrán megfigyelhető a határréteg rács, amelyre azért van szükség, mivel a differenciálegyenletekben található fizikai mennyiségek deriváltjai (sebesség komponensek és a hőmérséklet mezö) a falra meröleges irányban a legnagyobb értéküek.

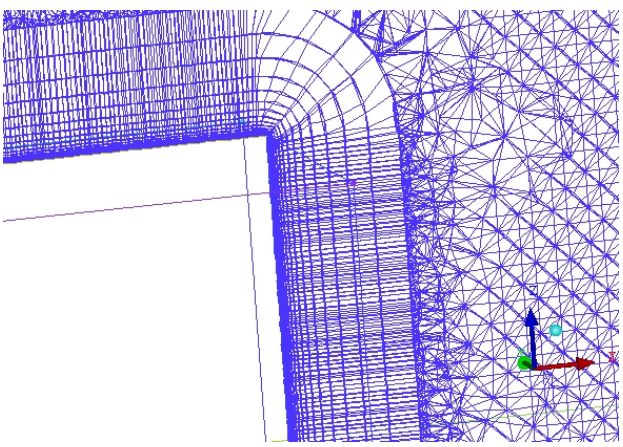

2. ábra. Az alkalmazott numerikus rács felépitése a hasáb körül

\section{Eredmények}

A bemutatott numerikus modellnél a hőátadási tényező meghatározásához a szigeteletlen betonkocka köré szabad áramlású levegőt illesztettünk. A program számszerüen meghatározta a hőátadási tényező értékeit az idő és a felületi koordináta függvényében. Ebből számítottunk egy $h$ átlagértéket, amely $7 \mathrm{~W} / \mathrm{m}^{2} \mathrm{~K}$ - re adódott. A kapott átlagértékkel a szakirodalomban is 
szokásos módon elvégeztük a numerikus számítást, amely eredményeit az előző méréssel együtt mutatja a 2. táblázat 13,6 óránál.

2. táblázat. A numerikus számítások eredményei

\begin{tabular}{|c|c|c|c|}
\hline $\begin{array}{c}\text { A beton anyagtulajdonságai: } \\
\mathrm{c}_{\mathrm{p}}=1128 \mathrm{~J} / \mathrm{kg} \mathrm{K} \text { és } \\
\lambda=3,5 \mathrm{~W} / \mathrm{mK}\end{array}$ & $\begin{array}{c}\mathrm{T}_{\min } \\
{\left[{ }^{\circ} \mathrm{C}\right]}\end{array}$ & $\begin{array}{c}\mathrm{T}_{\max } \\
{\left[{ }^{\circ} \mathrm{C}\right]}\end{array}$ \\
\hline \multirow{2}{|c}{$\begin{array}{c}\text { Hőelvonás } \\
\text { módja }\end{array}$} & levegő & 64 & 85 \\
\cline { 2 - 4 } & $\mathrm{h}=7 \mathrm{~W} / \mathrm{m}^{2} \mathrm{~K}$ & 54 & 83 \\
\hline
\end{tabular}

A $T_{\min }$ a betonkocka felszínén, a $T_{\max } a$ szerkezet közepén számított hőmérsékleteket mutatja.
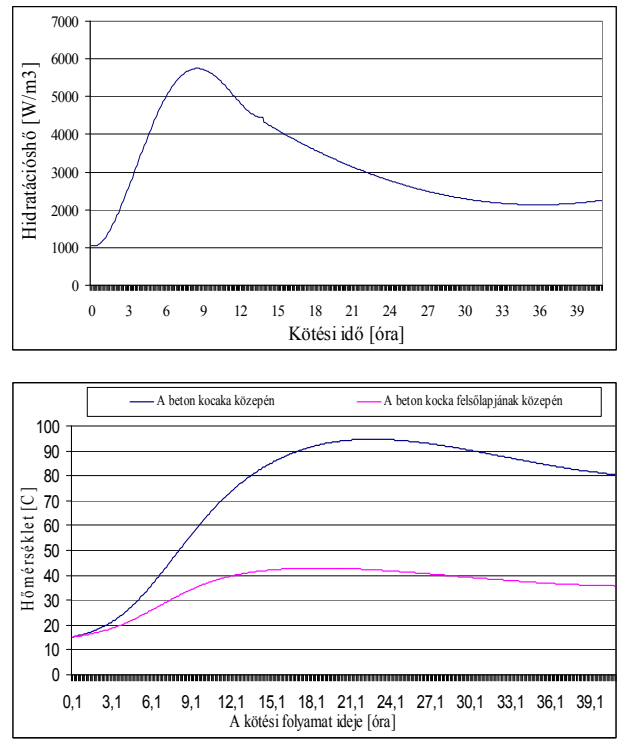

3. ábra Kötéshö és beton hömérséklet változása

A 3. ábrán bemutatott eredmények jellegére összevágnak az irodalomban leírtakkal, a hidratációs hőmennyiség a maximumát 8 óra, a hőmérséklet pedig 20 óra tájban éri el.

\section{Következtetések}

A hőátadási tényező meghatározására a szakirodalom nem ad egyértelmü módszert. Az előzőekben egy új megközelítést mutattunk be, amely ennek meghatározását lehetővé teszi. A konkrét számértékek biztonságos meghatározásához további kutatási munkát kell elvégezni. A 2. táblázatban láthatóan a beton magban alig van hömérséklet-különbség. A felületen lévő hőmérséklet különbséget úgy lehet javítani, hogy az új modellnél a $h$ hőátadási tényező változó értékeiből más módszerrel kell az átlagos értéket meghatározni. Ez után pedig azt kell megvizsgálni, hogy mely jellemzők határozzák meg a felületi hőátadási tényezőt és ki kell dolgozni az ezen jellemzőktől való függést meghatározó kapcsolatot. Ehhez a továbbiakban elengedhetetlennek bizonyul a különböző paraméterek mérése $\left(\mathrm{q}, \lambda, \mathrm{c}_{\mathrm{p}}\right)$ ill. számítása.

\section{Szakirodalmi hivatkozások}

[1] Dr. Balázs György: Különleges Betonok és betontechnológiák I., Akadémiai Kiadó, Budapest, 2007, ISBN 978-963-05-8465-4

[2] G. De Schutter, M. Vuylsteke: Minimisation of early age thermal cracking in a J-shaped non-reinforced massive concrete quay wall, Engineering Structures 26, 2004 pp. 801-808

[3] B. Klemczak: Engineering Structures: Reinforced concrete tank walls and bridge abutments: Early-age behaviour, analytic approaches and numerical models 84 (2015) pp 233-251

[4] Yunus Ballim: A numerical model and associated calorimeter for predicting temperature profiles in mass concrete, Cement \& Concrete Compositers 26, 2004, pp. 695-703

[5] A.K. Schindler és mások: Concrete pavement temperature prediction and case studies with the FHWA HIPERPAV models, Cement \& Concrete Compositers 26, 2004, pp.463-471 